\title{
ARTICLES
}

Submitted 10.05.2015. Approved 05.03.2017

Evaluated by double-blind review process. Scientific Editor: Thomas Brashear Alejandro

DOI:http://dx.doi.org/10.1590/So034-759020170506

\section{THE TASTE TRANSFORMATION RITUAL IN THE SPECIALTY COFFEE MARKET}

\author{
Ritual de transformação do gosto no mercado dos cafés especiais \\ El rito de la transformación del gusto en el mercado de los cafés especiales
}

\begin{abstract}
Although the consumer culture field has addressed the role of ritual processes in consumption, no research has yet identified how connoisseur consumers, through ritual practices, establish and manipulate their distinction from other consumers. Drawing on key concepts from ritual theory, this research addresses the role played by ritual in connoisseurship consumption and consumers' taste. In conducting an ethnographic study on connoisseurship consumption, the first author immersed himself in the North American specialty coffee context-Toronto, Montreal, Seattle, and New York-from August 2013 to July 2014. He used long interviews and participant observation to collect data, which was then interpreted using a hermeneutic approach. We introduce the taste transformation ritual, theorizing the process that converts regular consumers into connoisseur consumers by establishing and reinforcing differences between mass and connoisseurship consumption. We develop a broader theoretical account that builds on consumption ritual and taste formation.
\end{abstract}

KEYWORDS | Consumption ritual, connoisseurship consumption, taste, ethnography, specialty coffee.

\begin{abstract}
RESUMO
Apesar do campo da cultura de consumo ter realizado diversas pesquisas sobre o papel do ritual no consumo, nenhuma pesquisa, até então, identificou como o consumidor apreciador, por meio de práticas rituais, estabelece e manipula sua própria distinção em relação aos demais consumidores. Tendo como base conceitos da teoria sobre ritual, esta pesquisa explica o papel desempenhado pelo ritual no consumo de apreciação e no gosto do consumidor. Realizando um estudo etnográfico sobre o consumo de apreciação de cafés especiais, o primeiro autor mergulhou no contexto da América do Norte - Toronto, Montreal, Seattle e Nova lorque - de agosto de 2013 a julho de 2014. Ele utilizou entrevistas longas e observação participante para coletar os dados, que foram interpretados utilizando a abordagem hermenêutica. Foi introduzida a ideia do ritual de transformação do gosto, teorizando sobre o processo que converte consumidores regulares em apreciadores por meio do estabelecimento e reforço das diferenças existentes entre o consumo de massa e de apreciação. Desenvolveu-se uma ampla explicação teórica baseada no ritual de consumo e formação do gosto.
\end{abstract}

PALAVRAS-CHAVE / Ritual de consumo, consumo de apreciação, gosto, etnografia, café especial.

\section{RESUMEN}

Aunque el campo de la cultura consumista ha tratado el papel de los procesos rituales en consumo, aún no se ha identificado cómo los consumidores entendidos, a través de prácticas de ritos, establecen y manipulan su distinción de los demás consumidores. Utilizando los conceptos clave de la teoría ritual, este estudio trata el papel desempeñado por los ritos en el consumo y gusto de conocedores entendidos. Al conducir un estudio etnográfico sobre consumo de entendidos, el primer autor realizó una inmersión en el contexto de los cafés especiales de América del Norte (Toronto, Montreal, Seattle y Nueva York), de agosto de 2013 a julio de 2014. Usó largas entrevistas y observación de participantes para reunir datos, que después se interpretaron utilizando un abordaje hermenéutico. Introducimos el rito de transformación del gusto teorizando el proceso que convierte consumidores comunes en consumidores entendidos al establecer y reforzar opuestos entre consumo masivo y consumo de entendidos. Elaboramos una explicación teórica más amplia que se basa en el rito de consumo y la formación del gusto.

PALABRAS CLAVE / Rito de consumo, consumo de entendidos, gusto, etnografía, café especial. 


\section{INTRODUCTION}

The consumer culture field has addressed the role played by ritual in consumption (Kozinets, 2002a; McCracken, 1986; Muniz \& O'Guinn, 2001; Nguyen \& Belk, 2013; Rook, 1985; Schouten \& McAlexander, 1995; Sherry, Jr., 1983), defining and describing this construct and explaining its dimensions, cultural meanings, elements, components, and practices, as well as revealing the differentiations in consumer ritual practices. Rook's (1985) seminal paper influenced various studies on ritual consumption. He focused on structural elements to describe rituals: the artifact, script, roles, and audience. Recently, Arsel and Bean (2013) used Rook's perspective to describe the ritualization of taste regimes, and Karababa and Ger (2011) identified Ottoman coffeehouse consumption as a ritualistic pursuit of leisure using Rook's ritual elements as the basis of analysis. Turner's ritual process theory describes the individuals' transformation through the rite of passage explained by Van Gennep (1960) and explains the formation of communitas. It has also been used by many consumer culture studies to understand the role played by consumption ritual (e.g., Belk, Sherry, \& Wallendorf, 1988; Kozinets, 2001; Thomas, Price, \& Schau, 2013). Using Turner's theoretical lens, Belk and Costa (1998) introduced the ritual of transformation; Belk, Wallendorf, and Sherry (1989) explained sacralization through ritual; and Kozinets (2002a) investigated the self-transformative ritual power provided at Burning Man festivals.

However, no research has yet identified how connoisseur consumers, through ritual practices, establish and manipulate their distinction from other consumers and the transformation of their tastes to achieve this status. Ritual in connoisseurship consumption plays a transformative role as one's tastes change. Taste "is not given or determined, and their objects are not either; one has to make them appear together, through repeated experiments, progressively adjusted" (Hennion, 2007, p. 101). Taste is continually achieved (Arsel \& Bean, 2013). Drawing on key concepts from ritual theory, our research addresses the role played by ritual in connoisseurship consumption and explains how regular connoisseur consumers transform their tastes and themselves.

In taking a sociocultural approach, we interpret our qualitative data on specialty coffee consumption by drawing on key concepts from ritual theory. We then introduce the taste transformation ritual, theorizing the process that converts a regular consumer into a connoisseur consumer. By performing taste transformation rituals, some coffee consumers transform themselves, establishing and reinforcing the oppositions between mass and connoisseurship consumption. The taste transformation ritual involves (1) using taste in a reflexive way for different "highquality" products, (2) choosing the right place and (3) moment to appreciate the product, (4) paying special attention during the tasting act, (5) persevering in connoisseurship consumption, (6) investing time and money, and (7) increasing the connoisseur's subcultural and social capital. In the general taste transformation ritual, connoisseur consumers put taste to the test and train themselves to develop abilities and sensibilities to perceive the properties of objects.

The specialty coffee context was chosen for this study because of several important features. Kozinets (2002b), studying coffee consumption online in the late 1990s, revealed that Starbucks raised coffee consciousness and increased the number of coffee connoisseurship practices. Starbucks (with 15,000 stores worldwide) influenced the marketplace culture in the 1990 s and 2000 s (Thompson \& Arsel, 2004; Thompson, Rindfleisch, \& Arsel, 2006). In the 2000s, some independent coffee shops began to position themselves to cater to a growing number of consumers who were concerned about quality, variety, artisanal foodstuff, and brewing methods. These consumers play an increasingly important role in the market (Skeie, 2003). In this context, coffee connoisseurship consumption practices are ritualistic pursuits of leisure.

Based on an ethnographic study of connoisseurship in specialty coffee consumption, we develop a broader theoretical account that builds on ritual consumption. We next review theories about consumption rituals, define the connoisseur consumer and concepts of serious leisure, explain taste as a reflexive activity, and describe the research context (i.e., specialty coffee). We then present the methods used in our qualitative research and describe our research findings. Finally, we discuss the results and consider future research.

\section{CONSUMPTION RITUAL}

Ritual has been a fertile research domain for researchers in the field of consumer culture theory and has been used to understand the meanings of consumption and consumer behavior more broadly. Rook (1985) introduced and elaborated on the ritual construct as a vehicle for interpreting consumer behavior. McCracken (1986) analyzed the movement of cultural meaning theoretically and suggested that advertising, the fashion system, and rituals (possession, exchange, grooming, and divestment) are responsible for this movement. Belk et al. (1989) describe sacralization rituals, and Sherry (1983) explains interaction rituals in the gift-giving process. Ritual also plays an 
important role in understanding the consumption of the American Thanksgiving holiday (Wallendorf \& Arnould, 1991), activities within consumption subcultures (Schouten \& McAlexander, 1995), the creation of fantasy consumption enclaves (Belk \& Costa, 1998), brand communities (Muniz \& O’Guinn, 2001), Burning Man consumption (Kozinets, 2002a), intracommunity gifts (Weinberger \& Wallendorf, 2012), death and identity (Bonsu \& Belk, 2003), the wedding harmonization process (Nguyen \& Belk, 2013), the lavish wedding (Otnes \& Pleck, 2003), and the meaning of alcoholic beverages to college students (Wolburg \& Treise, 2004).

In the consumer culture field, Rook's (1985) definition of ritual and McCracken's (1986) analysis of the four consumption ritual processes (exchange, possession, grooming, and divestment) have been applied by many scholars (e.g., Arsel \& Bean, 2013; Karababa \& Ger, 2011; Russell \& Levy, 2012). According to McCracken (1986), "Ritual is an opportunity to affirm, evoke, assign, or revise the conventional symbols and meanings of the cultural order" (p. 78). Ritual has been defined by Rook (1985, p. 252) as "a type of expressive, symbolic activity constructed of multiple behaviors that occur in a fixed, episodic sequence, and that tend to be repeated over time." Rook (1985) describes personal rituals and focuses on the structural elements of ritual, listing four tangible components present in coffee connoisseurship consumption practices: (1) artifact (specialty coffee), (2) ritual script (visiting different coffee shops, greeting and conversing with the barista, the tasting act, and a farewell), (3) roles performed by connoisseur consumers in different stages of their journey (the beginner, intermediate, and advanced connoisseur consumers), and finally, (4) audience (friends, family, and other connoisseurs).

Producing ritualized acts (ritualization) is a strategy for differentiating oneself, considering various degrees to which and ways in which an entity can separate "itself off from other ways of acting by virtue of the way in which it does what it does" (Bell, 1992, p. 140). Bell (1992) explains the systematic dimensions of ritualization, which helps to understand the strategies used by consumers to establish and manipulate their consumption differentiation, through the three interrelated sets of oppositions: 1) the vertical opposition of superior and inferior, "which generates hierarchical structures," 2) the horizontal opposition of us and them, "which generates lateral relationships," and 3) the opposition of central and local, "which frequently incorporates and dominates the preceding oppositions" (Bell, 1992, p. 125). The oppositions between mass and connoisseurship consumption practices, which are highlighted during the taste transformation ritual, are fundamental to maintaining and reinforcing the differences between the connoisseur and regular consumers.

\section{CONNOISSEURSHIP CONSUMPTION}

Connoisseurship means applying a highly nuanced schema to understand, evaluate, and appreciate consumption objects (Holt, 1998). A connoisseur consumer has differentiated consumption knowledge compared to other consumers due to his or her expertise or taste in the marketplace (Bourdieu, 1984). Consumers produce subjectivity through connoisseurship (Holt, 1998). The connoisseur consumer is empowered by field-specific cultural competence, cultural and social capital (Bourdieu, 1984), genuineness (Kozinets, 2002b), and discernment (Ahuvia, 2005). Ahuvia (2005) describes examples of connoisseurship in which everyday items (cartoons and popcorn) are appreciated in terms of abstract aesthetic properties and high levels of expertise. Connoisseur style is expressed through consumption practices, even if the object itself is widely consumed, like coffee. Connoisseurs accentuate specific aspects of the consumption object and develop "finely grained vocabularies to tease out ever more detailed nuances within a category, [...] and the ability to engage in passionate appreciation of consumption objects meeting one's calculus of 'quality' within a category” (Holt, 1998). Connoisseur consumers have values that differ from those of mass consumption, achieving status by inverting mainstream values. They distinguish themselves by adopting consumption practices contrary to mass consumption and popular culture. "Popular culture is mass-produced for mass consumption," (Storey, 2009, p. 8) and its audience is a mass of non-discriminating consumers.

Elliott (2006) suggests that many objects that were outside the realm of connoisseurship have now entered this realm (e.g., in the rise of specialty coffees like those at Starbucks). Many objects previously located squarely within the realm of connoisseurship have been democratized (just as demystification of a wine makes it more popular). Elliott (2006) calls this movement the "democratization of taste and the construction of contemporary connoisseurship" (p. 230). This movement is communicated to consumers by marketing campaigns, magazines, websites, radio, television, newspaper, and articles. Consequently, connoisseurship practices have increased in the marketplace. However, while democratization of connoisseurship practices increases the number of consumers who demand products labeled with a different status by the marketplace for a particular type of good, some consumers still search for exclusivity "through the purchase of distinctive clothing, foods, automobiles, houses, or anything else that individuals may believe will in some way set them off from the mass of mankind" (Leibenstein, 1950, p. 184). Called the "snob effect" (Leibenstein, 1950), connoisseur consumers keep developing distinct connoisseurship practices to differentiate themselves from other consumers. 


\section{TASTE AS A REFLEXIVE ACTIVITY}

Taste has been theorized by many scholars as a system of classification and distinction structured through material culture (Barcelos, 2015; Bourdieu, 1984), such as differences in cultural capital resources structuring patterns of taste and consumption (Holt, 1998), and the status consumption in less economically developed countries being based on the consumer goods and services prevalent in more economically developed countries, including homes, interior decor, clothing, vacations, and shopping (Ponte \& Mattoso, 2014; Üstüner \& Holt, 2010). Bourdieu's (1984) concept of cultural capital and its class-bound resources such as occupation, profession, and education has been used by many scholars to understand the role played by taste in consumption (Coskuner-Balli \& Thompson, 2013; Holt, 1998; McQuarrie, Miller, \& Phillips, 2013; Roling \& Vieira, 2014; Üstüner \& Holt, 2010). While Bourdieu's cultural capital concept presumes a static social taste arrangement, Gronow (1997) discusses taste in the dynamic, contingent, and transitory context of the standards of food fashion. He proposes that people can be differentiated as those who have good taste (good society) and those who do not (bad society). Everyone is supposed to choose what feels good, but "the ideal of good taste is meant to be beyond the individual, and to be socially binding. It offers a universal standard, potentially applicable to all members of a society" (Gronow, 1997, p. 91). Becker (1982) explains the importance of rationales to identify good taste in the art world. Rationales "typically take the form of a kind of aesthetic argument, a philosophical justification, which identifies what is being made as art, as good art, and explains how art does something that needs to be done for people and society" (Becker, 1982, p. 4).

Following Hennion (2004) and Arsel and Bean (2013), who question the idea of taste as a passive social game or static state of affairs and consider taste a reflexive activity rather than an attribute or property (of a thing or person), we ask how connoisseur consumers, through ritual activities, establish and manipulate their own taste differentiation by comparing them to other consumers. In our view, taste does not come from things themselves (natural interpretation), and the objects are not what we make them (cultural interpretation). Taste is not given or determined, nor are its objects. Taste instead results from the performance of a person, based on corporeal training, comparison, and repeated experiments, and is progressively adjusted. Through ritual, which compresses the elements of reflexive taste and works as the medium between object and culture, connoisseur consumers transform their tastes in a reflexive way. Connoisseur consumers are the "reflexive result of a physical and collective practice, one that entails the use of equipment of all kinds and is regulated by methods that are themselves constantly revised" (Hennion, 2004, p. 135). They develop taste by performing reflexive work through a continuous elaboration of procedures and training that put taste to the test to develop abilities and sensibilities to perceive objects' properties (Hennion, 2007). Taste is not given but produced; consequently, reflexivity is a central modality of connoisseur consumers' activities.

\section{THE SPECIALTY COFFEE CONTEXT}

Coffee consumption plays an important role in consumer culture. Sherry (1995) interpreted coffee's cultural meanings as depicted on prime-time network television programming, noting that coffee is "perhaps the primary key symbol in contemporary consumer culture" (p. 357). Although coffee is considered the beverage of postmodernism (Roseberry, 1996), it has played an important role in consumer culture since the mid-sixteenth century; Karababa and Ger (2011) have researched the formation of the consumer subject in Ottoman coffeehouse culture. In the last two decades, coffee consumption culture has evolved significantly, because of the famous global brand, Starbucks. Academic interest in specialty coffee consumption has arisen from or is mostly focused on Starbucks. Many marketing research studies have analyzed the influence of Starbucks in the marketplace, such as consumers' (anticorporate) experiences of globalization (Thompson \& Arsel, 2004), emotional branding and doppelgänger brand image (Thompson et al., 2006), hegemonic brandscapes (Thompson \& Arsel, 2004), boycotts and out-sourcing of politics (Simon, 2011), and global consumer culture in Scandinavia (Kjeldgaard \& Ostberg, 2007).

Erna Knutsen, of Knutsen Coffee Ltd., coined the term "specialty coffee" in 1978, referring to beans with unique flavor profiles produced in special geographic microclimates. Specialty coffee is "defined by the quality of the product, whether green bean, roasted bean, or prepared beverage, and by the quality of life coffee can deliver to all of those involved in its cultivation, preparation, and degustation" (Rhinehart, 2009). The Specialty Coffee Association of America (www.scaa.org) states that specialty coffee has superior quality. The expression "superior quality" in the marketplace differentiates specialty coffee from regular coffee. Although the specialty coffee market was a new market segment opportunity in 1980, together with the establishment of the Specialty Coffee Association of America in 1982, the specialty coffee business became significant in the U.S. "during the 1960s, with sales amounting to about $\$ 45$ million in 1969. The segment 
grew enormously during the late 1980 s rising by $\$ 2$ billion in 1994 and \$9 billion in 2003" (Cassia, Fattore, \& Paleari, 2006). Cassia et al. (2006) note that, despite originating in a small niche, specialty coffee has topped traditional products' retail sales since the beginning of the 2000 s.

\section{METHODS AND DATA COLLECTION}

A qualitative study of connoisseur consumers' behavior and rituals was conducted to answer our research question: What is ritual's role in connoisseurship consumption? The first author immersed himself in the field, starting the research as a regular coffee consumer. He tasted many coffee types at Starbucks, including Frappuccinos, Caramel Macchiatos, and Americanos, and then moved to high-end independent coffee shops (hereafter abbreviated HEICSs), tasting a variety of single-origin coffee brewed using different methods and equipment such as Chemex, V6o Hario, Siphon, French Press, and AeroPress. Finally, he began tasting espresso, getting deep inside the specialty coffee community. Adopting a naturalistic inquiry approach (Belk et al., 1988), he joined the specialty coffee community and increased his coffee knowledge and taste as a fully participating member of this consumption culture (Arnould \& Wallendorf, 1994). To extract the meanings embedded in coffee connoisseurs' ritual behaviors, the first author conducted intensive and openended interviews, as suggested by Rook (1985). The interviews, conducted as special conversations (Belk, Fischer, \& Kozinets, 2013), were unstructured with open-ended questions and held on-site (HEICSs). A phenomenological interviewing approach (Thompson, Locander, \& Pollio, 1994) encouraged informants to describe their consumption practice with rich, descriptive details. Interviews were recorded and transcribed. Our data set includes 20 on-site, in-depth coffee consumer interviews (1.668 minutes), 15 in-depth coffee professional interviews (855 minutes), 377 pages of field notes; and 551 photographs. Pseudonyms are used to guarantee informants' confidentiality.

To identify coffee connoisseur consumers, we used a criterion sampling strategy (Miles \& Huberman, 1994) involving consumers at HEICSs who drank coffee without milk and sugar and who interacted with the barista, asking questions about coffee. Based on the first interview experiences with connoisseur consumers, we used "purposive sampling design" (Belk et al., 1988, p. 453) and snowball sampling (Miles \& Huberman, 1994), aided by the initial informants.

The first author visited and observed consumers in 48 independent coffee shops (most of them HEICS): nine in Seattle, nine in New York, 28 in Toronto, and two in Montreal. The criteria to define independent coffee shops as high-end were based on informants' opinions, baristas' opinions, and the quality of coffee served during the first author's visit. He attended three coffee club meetings: two in Seattle, one involving eighteen people (three hours and thirty minutes) and one involving four people (one hour and thirty minutes), and one in Toronto involving three people (three hours); he also attended eight coffee cuppings: five in Seattle and three in Toronto (seven hours and fifty minutes). He attended the $27^{\text {th }}$ annual exposition of the Specialty Coffee Association of America in Seattle.

This paper details the meanings and practices associated with the coffee taste transformation ritual in the context of North American specialty coffee consumption. Qualitative data was interpreted using a hermeneutic approach (Thompson, 1997), comparing consumers' stages in their coffee connoisseurship knowledge and experience and studying “differences between newcomers and those who have long been members" (Belk et al., 2013, p. 148). The second and third authors interacted with the first author during data collection and jointly interrogated the written research material.

\section{THE TASTE TRANSFORMATION RITUAL}

Coffee connoisseurship consumption is based on the performance of the taste transformation ritual (i.e., tasting different kinds of high-quality coffee prepared by different well-trained professionals in different coffee shops, taking time to feel the coffee tasted during the sip and engaging in a conversation with the barista or friend about the coffee's aroma, flavor, and taste). The taste transformation ritual usually occurs at moments during the day in which the coffee, in the coffee connoisseur consumer's opinion, could be well prepared (in some cases, best prepared) in highend independent coffee shops, depending on the weather, barista, and coffee equipment conditions. The tasting ritual is performed frequently and continuously, and coffee connoisseurs persevere for years, varying their choices of high-quality coffees and visiting other neighborhoods, cities, and even countries, where there are specialty coffee scenes. The tasting act is a reflexive moment. It is a pause and an act of attention to the coffee. During this moment, the object being tasted has a strong presence in the connoisseur consumer's attention. Coffee connoisseurs invest time and money to develop knowledge and taste.

Espresso is the preferred coffee beverage of connoisseur consumers in the advanced stage of connoisseurship consumption. In the coffee context, according to Kozinets (2002b) "the subtle 
inculcation of coffee tastes (on a trajectory culminating in a taste for espresso) is often mapped out in coffeephile communications, tracing a gustatory route through, for example, Cappuccino, Macchiato, and con pannas to espresso" (p. 68). Adults or those informants who have been performing the taste transformation ritual for many years prefer espresso, a finely-ground coffee brewed under pressure for up to a minute. ChefSteps (2014) explains that espresso can be prepared using a brew ratio (weight of grounds to liquid) from 1:1 to 1:3 (depending on the country), a brew time (water duration through portafilter) of 25-35 seconds, and a brew temperature (usually set by the machine) of $195^{\circ} \mathrm{F}-203^{\circ}$ F. According to ChefSteps, in North America espresso is a $36-\mathrm{ml}$ beverage made with 18 grams of ground coffee (brew ratio of 1:2).

Espresso is difficult to make at home, because of the investment in equipment (grinder and espresso machine), training (formal and at home), and time necessary to develop the ability to make a great shot. Although some coffee connoisseur consumers have more knowledge and skill than many baristas, they cannot accomplish the work of outstanding or champion baristas. Beyond the skill developed by professionals during daily work practices (brain activities), they also have more cognitive responses during tasting than nonprofessionals (LaTour, LaTour, \& Feinstein, 2011). Professionals can, therefore, improve knowledge and taste faster than consumers. Nevertheless, the skills necessary to extract a great espresso shot are difficult to develop, even for a barista who has worked in coffee shops for a long time.

To initiate connoisseurship consumption (Figure 1), the consumer must identify HEICSs near home or work and taste espresso. Engaging in the coffee connoisseurship community, improving taste, and understanding more about the specialty coffee consumption culture, they progress by exploring new HEICSs in their own city and in other cities, states, and countries. The increased subcultural and social capital and the number of HEICSs visited by coffee connoisseur consumers during their rites of passage are represented by the "V" figure. The connoisseur consumers' stage in connoisseurship consumption is influenced by their level of engagement in the coffee connoisseurship community and their access to HEICFs to perform the taste transformation ritual. Connoisseur consumers choose some HEICSs to visit more frequently than others, as represented in the figure by the circle size. Among all HEICSs, some are considered the best and are represented by the darker circle color.

\section{Figure 1. Connoisseurship consumption (from regular to connoisseur consumers) and the elements of the taste transformation ritual}

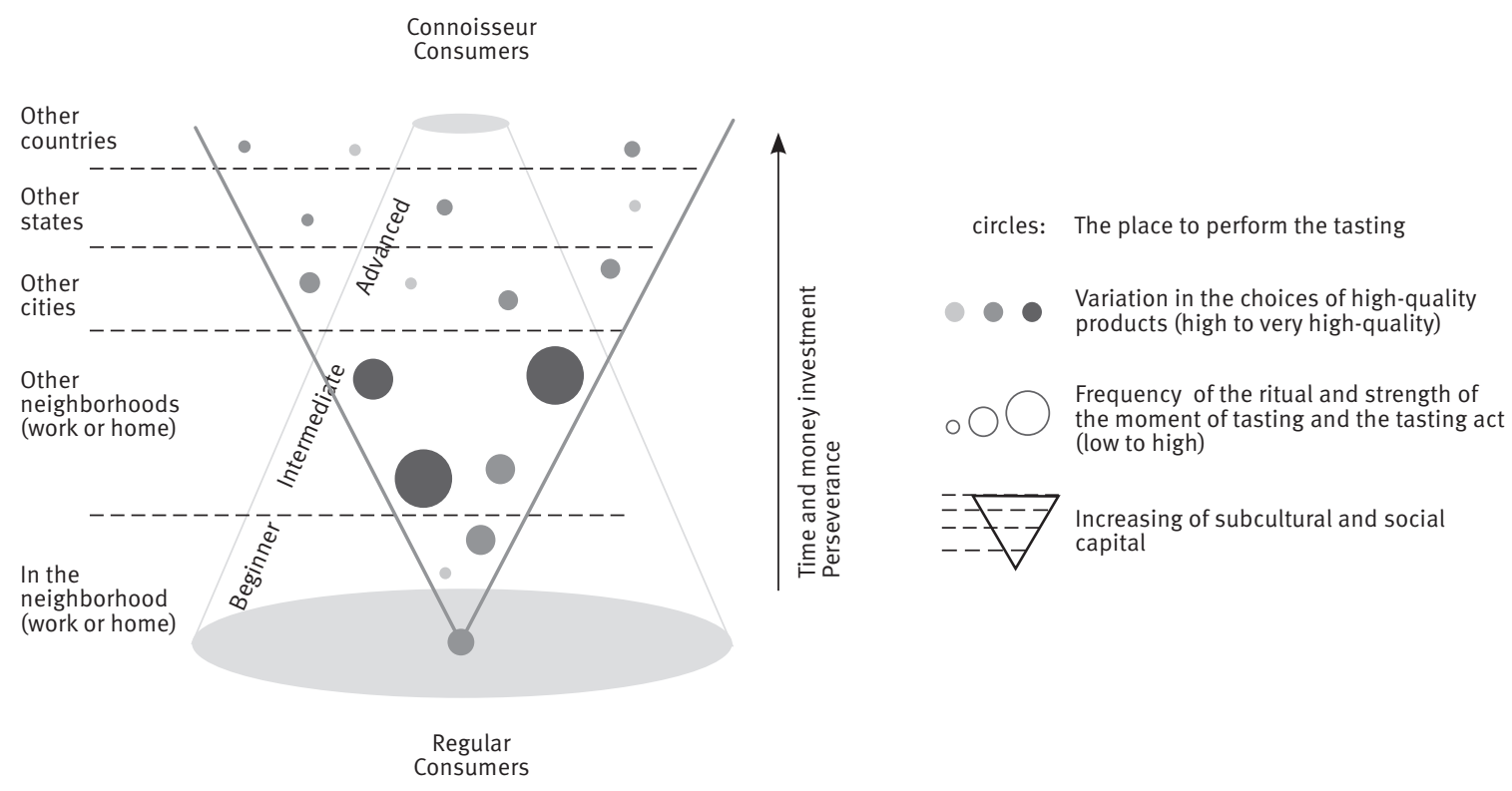

All seven elements of the taste transformation ritual are presented in Figure 1: (1) variation in the choice of high-quality products, (2) place to perform the tasting, (3) moment of tasting, (4) tasting act, (5) time and money investment, (6) increased subcultural and social capital, and (7) perseverance. 


\section{Variation in choice of high-quality products}

The taste transformation ritual is based on the high quality of the product served by HEICSs. Connoisseur consumers search for high-quality products to identify nuances and challenge their palates and tastes. Lower-quality coffees do not have different aromas and tastes because the beans are not good, they are poorly farmed/processed, or are roasted incorrectly (over- or under-roasted). Consumers achieve a reflexive taste when they consume a high-quality product. The informants care more about high-quality coffee than other things. Suzy ( 28 years old, Biochemist, 13 years performing the ritual) explains how she deals with the trade-off between fair trade/direct trade and highquality coffee. She always considers quality when buying coffee:

For me, personally, will I select something that's direct trade over not direct trade? No, I think I will select it based on the origin more than direct trade versus... Will I buy from a roaster that's fair trade more than not fair trade? No, because I want to know that somebody's producing an exceptional product. There are many roasters that say there's fair trade, or free trade, or direct trade. Great. But if you don't have a product that's good, I'm not going to buy it.

However, drinking the same high-quality coffee provided by HEICSs does not allow connoisseur consumers to develop their taste. The informants vary the high-quality coffee they drink as much as possible. Variation in choice of high-quality coffees reflects consumers' taste transformation when connoisseur consumers "go from homogeneity to heterogeneity in the substances themselves and/or in the variety available for choice" (Levy, 1999, p. 253). Each coffee connoisseur consumer and barista the first author interviewed gave him a list of HEICSs to visit. Greg (37, architect, Toronto, 15 years performing the ritual) gave the first author advice to improve his taste: "Definitely go visit as many of these guys [HEICSs] as possible, and keep visiting them because the flavors are very different from place to place." The informants seek novelty in coffee shops in their cities or in other cities as much as possible. Alan (51, vendor engineer, Seattle, seven years performing the ritual) combines his work travels or family travels with his interest in trying new coffee shops. John (32, marketer, Portland, eight years performing the ritual) takes advantage of the opportunity to work outside the office whenever possible; sometimes he goes to another city to taste coffee. Paul always buys specialty coffee when he travels.

\section{The place to perform the tasting}

HEICSs are places where connoisseur consumers perform taste transformation rituals. Informants do not try coffee in coffee shop chains (e.g., Starbucks, Tim Horton's, and Timothy's Cafe) because of the uniformity and predictability (Ritzer, 2007) of coffee taste, their perception of low coffee quality, and the coffee shop chains" "commodity logic" (Thompson \& Arsel, 2004, p. 639). Coffee shop chains represent mass consumption and the real world. In the HEICS craft tradition, consumers and professionals can retain some control over every stage, or almost every stage, of manufacture, "and thereby gain a far more satisfactory relationship with the product" (Miller, 1997, p. 140). HEICSs promote a "conspicuous handmade image, explicitly separate from the products of mass consumption, and immediately recognized as a quality product" (Miller, 1997, p. 140). In HEICSs, consumers can taste different high-quality coffees prepared by well-trained baristas who can help and guide them during their taste transformation ritual. In HEICSs, connoisseur consumers can find specialty coffee from different single origins (e.g., coffee microlots from different farmers in countries such as Brazil, Colombia, Rwanda, and Ethiopia) with different roasting points that extract different flavors from the same green coffee beans. The informants like to explore these places, tasting as many coffees as possible and verifying what places are better than others. As Jane explains, "What I discovered was, as I was getting it out of necessity, you could say, if I got it from one place or another, I noticed I liked one place better than another, and so forth."

\section{The moment of tasting}

The moment during the day and during the week to perform the connoisseurship consumption ritual is important to the informants. Hennion (2007) affirms that the consumer's pleasures depend on places and moments, and the informants consider many factors when determining the best situation in which to taste their coffee in HEICSs. Hennion argues, "Far from being trivial, the process of creating the right mood for passion, through all the practices and rituals surrounding the act of listening, must be taken seriously" (2001, p. 12). Based on her own taste transformation ritual, Suzy describes the best moment to have a coffee shop espresso:

What I found was, it is actually better to not come during the morning rush at 7 to 9 . Not very good to taste coffee. It is better to taste coffee between $10[\mathrm{AM}]$ and 12 [PM], because the machine has 
warmed up in the coffee shop. So then I realized, I consistently go to coffee shops during that time from 10 to $12 \ldots$ It is the prime time. This is like the best time to come to a coffee shop. It is also quieter from 10 to 12 . There is no morning rush. I can sit, I can enjoy the coffee, I can talk to the barista after.

The informants and coffee professionals (barista and coffee shop owners) revealed that to taste a great espresso, the moment should be considered: the temperature, humidity, sun, barista's mood, noise level, and condition of the machine and devices. The espresso effects "do not depend only on the product but also on its moments, deployment, and circumstances" (Hennion, 2004 , p. 134). The moment depends on many variables. Alan says the barista must adjust the grinder, machine, and coffee quantity during the day (especially in the morning), depending on climate conditions. If there is a large queue with many customers waiting for service, it influences the way coffee is served, as Alan explains: "The guy wakes up early morning, the guy wants to go to work, the guy doesn't want to know if the barista needs to adjust the grinder. So, the barista doesn't worry about that, he just keeps doing his job anyway. This consumer doesn't care about it."

\section{The tasting act}

In the HEICs, coffee connoisseurs want coffee to be mind-altering, as Hennion explains in the music context. Music lovers do not go to a concert to "consume a commodity or have one's membership card checked, but to bring about an altered state" (Hennion, 2001, p. 14). Generally, the informants drink espresso in three sips, and in each, the coffee will taste different. They do not know how the coffee tastes, even when they taste the same coffee at the same coffee shop. Hennion (2004) affims that "taste is discovered precisely from uncertainty, from variation, from a deepening of the effects of the product" (p. 137), and the informants prepare themselves for it. Beyond the condition and quality of the object tasted, the barista plays an important role during the tasting act. Hennion (2004) reveals that "there is no taste as long as one is alone, facing objects; no amateur knows from the outset how to appreciate a good thing, or simply what he likes. Taste starts with the comparison with others' tastes" (p. 137). Coffee connoisseurs compare coffee aroma and flavors and their own taste with the barista's taste. The barista helps improve the coffee connoisseurs' taste, guiding them during the tasting act, and telling them what to notice and perceive. According to Hennion (2004, p. 137), “Taste is formed as it is expressed and is expressed as it is formed." Informants rely on the barista to improve their taste. During the tasting act, coffee connoisseurs calibrate their palates, comparing their taste perceptions with the barista's. The taste transformation ritual allows consumers to develop and train their palates.

Coffee is a sensory hedonic product, or "an ambiguous product experience because the experience itself is not completely revealing and can be potentially interpreted in multiple ways" (LaTour \& LaTour, 2010, p. 690). The ability and knowledge to describe coffee aromas and tastes are essential to the development of consumer and professional taste: "Language is central to how consumers interpret, categorize, and remember their experiences" (LaTour et al., 2011, p. 3). Nevertheless, no informants, even those who were advanced, could identify all the tastes and aromas described by the Specialty Coffee Association of America (SCAA) in coffee. According to Alan, “After five years drinking coffee, I haven't developed my palate as I would like. People feel the flavor; I don't know, tangerine, sugar cane, you know? I am a liar. I pretend to feel the taste, but in fact I do not." LaTour and LaTour, studying how wine aficionados learn from experience, affirm that they "may go on for years drinking wine without learning from their experiences unless they activate and use conceptual knowledge to help them encode and retain their experiences in memory" (LaTour \& LaTour, 2010, p. 688). Connoisseur consumers lack conceptual knowledge because they are not trained as outstanding baristas.

\section{Time and money investment}

Taste is a collective, reflexive, instrumented activity that requires an investment of time and money by consumers to develop corporeal competency and build their social body through exercises guided by ritualization. Reflexive taste opens a space full of "objects and tools, devices, frames, confrontations, and references, of all kinds of supports, collectives, and material equipment" (Hennion, 2007, p. 109) that amateurs need to acquire or study to understand and produce differences from other consumers. Engagement in serious leisure pursuits demands time and money (Belk \& Costa, 1998; Stebbins, 1979), and all the informants try to balance their passion and life responsibilities. Alan does not drink coffee at home because "when you get inside of this, it has no end. You will start to invest money, you will start to invest time, and I don't have time and money to spend on this." However, John does not seem too worried about those issues. He invests his own time in specialty coffee, volunteering for SCAA events: 
I don't mind spending a whole bunch of money on it. It's what I like to talk about when I'm just relaxing. It's something I like to spend a lot of time on and have a lot of fun with... I got really into espresso, and it's a very expensive habit... I was probably spending 10 or 20 dollars a day just on espresso. I am volunteering [at an SCAA event] in the mornings.... I get there pretty early, like 7 or 8 , get in a couple of hours to volunteer. Then I come "up here" [to an HEICS] and get my real work done.

Regarding time, Frank (44, website designer, Seattle, 15 years performing the taste transformation ritual) said, "I don't have kids. I don't have a wife. I don't even have a cat. This isn't much time at all. I don't have to be in a commute." The informants admit to investing time studying and searching for coffee. Laura revealed that she used to spend almost two hours a week searching for new HEICSs to visit in the next coffee group meeting. She likes to search for coffee information on Google and takes her time with it. Joana, who is her friend and a coffee group member, said she is too busy to do it during the week. Joana takes advantage of Laura's commitment and interest in coffee consumption, but devalues it.

\section{Increasing subcultural and social capital}

Through the taste transformation ritual, the informants expand their coffee knowledge and gain subcultural capital (Thornton, 1996) within this specific field. The information exchange with baristas and coffee professionals and the different highquality coffee tastings in many HEICSs allow the informants to improve their subcultural capital. The performance of the taste transformation ritual continuously demarcates the boundaries of the connoisseurship consumption practices from which participants draw subcultural capital. Subcultural capital refers to the capacity to taste coffee in terms of connoisseurship consumption practices and is gained by performing the taste transformation ritual. Continuous participation in the specialty coffee consumption subculture allows the informants to invest in subcultural capital. Like fashion bloggers, connoisseur consumers are individuals "who start with some capacity for taste and proceed to accumulate cultural capital from its repeated exercise" (McQuarrie et al., 2013, p. 139) through the taste transformation ritual.

Sharing on social media also helps the informants improve their coffee knowledge, subcapital cultural, and social capital, defined in Bourdieu (1986) as "the aggregate of the actual or potential resources which are linked to possession of a durable network of more or less institutionalized relationships of mutual acquaintance and recognition" (p. 51). Advanced coffee connoisseurs largely use social media to follow the specialty coffee community. Frank complained about a new HEICS that has social media accounts but does not send updates about what they are doing: "They're doing the greatest things in the world and behind the door. For you to find that out, you actually have to go in and stand in line and ask them. There's no way for you to go to the website, Twitter feed, and Facebook and find out what they're doing. It's not approachable." On Twitter, coffee connoisseurs receive messages from baristas, HEICSs, and coffee companies, and they seek information about HEICSs, coffee novelties, events, meetings, and competitions. Alan explains how Twitter helps him gain more subcultural and social capital: "The coffee world here in the US is totally based on Twitter. I am active on Twitter, and everybody gets in contact on Twitter, all the baristas. You must follow people on Twitter." Belk explains, "the possibilities of digital sharing online foster feelings of community and an aggregate sense of self, even with others we would not recognize in person" (Belk, 2013, p. 486). In the social media world, coffee connoisseurs reach both a specific audience (coffee professionals and coffee connoisseurs) and mass audience (friends, family, and so on), thereby increasing their social capital.

\section{Perseverance}

Perseverance is required during the taste transformation ritual. The taste transformation ritual should be performed frequently and continuously. Informants in the advanced level have been performing the taste transformation ritual for at least five years. As a reward, after a while, the consumer has his or her taste transformed and forms part of the specialty coffee community, being recognized as a special consumer. If the informants persevere, they have a taste revelation at a moment some call an “epiphany” (Alan), a "click” (Frank), a "breakpoint” (Greg), or an "a-ha moment" (Suzy). This moment is called a "peak experience" (Maslow, 1964) or "ecstasy" (Belk et al., 1989) in the academic field. Usually, at this moment, something sublime happens. The informants (consumers and coffee professionals) remember the exact year, month, and day, the place, and the coffee they were drinking when they had their epiphany moments. For Alan, it was in 2009 at Fonte Coffee Shop when he could finally perceive the differences between coffees. John reveals, “'’ve never experienced that [feeling] before the coffee. It totally blew my mind." For Suzy, it was in 2009 at Ritual Coffee Shop in San Francisco: 
The big, the big, like, "wow," "a-ha moment" was when I went to San Francisco. So, in that little pocket in the downtown area, in one block there is so much variety. They are all good coffee. So that time, I said, like, "Wow, this is amazing." । didn't know that this is possible for a shot. I tasted all these different coffees. It was at Ritual Coffee. They had seasonal espressos. Very weird, like sugar, it was so sweet, very pleasant finish. It wasn't like a bitter taste that I was kind of tasting, you know that chocolate, that was so sweet... I was like, "Wow!" And that day, on that day... It was actually my fourth espresso.

\section{DISCUSSION}

Using a qualitative approach, we extend the notion of ritual in the consumer behavior field (McCracken, 1986; Rook, 1985) by introducing the taste transformation ritual. This ritual symbolically portrays the enthusiasts' strivings to differentiate themselves from regular consumers, which Leibenstein (1950) calls the "snob effect," through practices, objects, and taste. Tasting coffee in a reflexive way, paying attention to what they are drinking, and discussing it with friends and professionals allows them to change themselves and their bodies. McCracken (1986) affirms that rituals transform the individuals and Belk and Costa (1998) find that the creation of a fantasy consumption enclave created transformation rituals. We describe how regular consumers transform themselves and their bodies through taste transformation rituals and become connoisseur consumers.

Based on the oppositions described by Bell (1992), our findings demonstrate how taste transformation rituals are established and manipulated to differentiate connoisseurship consumption practices from mass culture practices. The contrast and comparisons between connoisseurship and mass consumption reveal the systematic ritualization dimensions described by Bell (1992). For the informants, in the vertical hierarchical structures generated by the oppositions, the independent coffee shop is superior and coffee chains are inferior. In the horizontal opposition, the distinction between connoisseur consumers ("us") and regular consumers ("them") is established. There is also an opposition between central and local coffee shops. The service and product provided by the central and hegemonic brandscape (Thompson \& Arsel, 2004) companies are the main oppositional references for the practices performed by connoisseur consumers in HEICs, which has the opposite effect to that suggested by coffee shop chains' commodity logic (Thompson \& Arsel, 2004).

We extend the taste theories by explaining how, regarding a specific aesthetic product category, people develop different tastes through ritualistic consumption. Taste has been studied as a static state of affairs or as a passive social game. Bourdieu (1984) distinguishes taste between classes (high, middle, and low class), and many researchers in the consumer culture field have focused on taste's role in perpetuating social hierarchies and distinctions (Holt, 1998; Üstüner \& Holt, 2010). However, our research addresses how aesthetic taste is formed through ritual consumption practices, independently from social class hierarchies.

Taste transformation rituals allow consumers to compare taste differences between mass and connoisseurship coffee consumption practices and develop their own taste and consumption practices. Contrary to Arsel and Bean (2013), who give attention to how individuals convert taste into practice, we argue that practice helps to convert the individual's taste through ritualization. Arsel and Bean (2013), based on Rook (1985), use structural elements (artifacts, script, performance, and audience) of the ritual, which are more personal and performance oriented, to explain the taste regime. However, our findings suggest that rituals studied as group-oriented practices better fit with the study of taste as a reflexive activity, due to the necessity of the social order and the community in transforming the consumer self. Thus, both individual sensory transformation of taste and social transformation of taste are part of these practices.

Connoisseur consumers develop their taste through a reflexive activity helped by professionals and other connoisseurs who encourage them. Furthermore, both sensory and cognitive transformations are needed to become a connoisseur. More metaphorically and socially, just as there is a bodily change in the individual in terms of sensory experiences, there is among the connoisseur community a change in the social body that is bound together by cognitive tastes that allow discourse about their shared pleasures (Gronow, 1997; Synnott, 1993; Turner, 1984). Additionally, just as sensory and cognitive transformations support one another, so do the individual and social bodily changes that occur. The study addresses not only connoisseurs and baristas, but also through the coffee growers, roasters, importers, shops, media, and others who play a part in provisioning, nurturing, experiencing, and sustaining the growing social body of contemporary coffee connoisseurship.

The present study's findings could be extended in future research exploring the different ritual functions. Other aggregate 
ritual functions could be addressed in the same context, such as initiation and bonding. Connoisseurship consumption is a richly ritualistic context that can help shed light on consumer behavior, expanding and developing the theory in the consumer culture field. The taste transformation ritual could thus be applied to other beverage or food contexts and to non-food and non-beverage contexts, such as art, film, and literature. These varied applications can provide a greater understanding of taste transformation rituals performed in the context of oppositional objects, practices, and meanings.

\section{REFERENCES}

Ahuvia, A. (2005). Beyond the extended self: Loved objects and consumers' identity narratives. Journal of Consumer Research, 32(1), 171-184. doi:10.1086/429607

Arnould, E. J., \& Wallendorf, M. (1994). Market-oriented ethnography: Interpretation building and marketing strategy formulation. Journal of Marketing Research, 31(4), 484-504. doi:10.2307/3151878

Arsel, Z., \& Bean, J. (2013). Taste regimes and market-mediated practice. Journal of Consumer Research, 39(5), 899-917. doi:10.1086/666595

Barcelos, A. (2015). O Gosto do consumidor: Reflexão teórica e conceptualização. Revista Interdisciplinar de Marketing, 5(2), 3-18.

Becker, H. S. (1982). Art worlds (p. 395). London, UK: University of California Press.

Belk, R. (2013). Extended self in a digital world. Journal of Consumer Research, 40(3), 477-500. doi:10.1086/671052

Belk, R. W., \& Costa, J. A. (1998). The mountain man myth: A contemporary consuming fantasy. Journal of Consumer Research, 25(3), 218-240. doi:10.1086/209536

Belk, R. W., Fischer, E., \& Kozinets, R. (2013). Qualitative consumer \& marketing research (First, p. 234). London, UK: SAGE Publications Ltd.

Belk, R. W., Sherry, J. F., \& Wallendorf, M. (1988). A naturalistic inquiry into buyer and seller behavior at a swap meet. Journal of Consumer Research, 14(4), 449-470.

Belk, R. W., Wallendorf, M., \& Sherry, J. F. (1989). The sacred and the profane in consumer behavior: Theodicy on the Odyssey. Journal of Consumer Research, 16(1), 1-38.

Bell, C. (1992). Ritual theory ritual practice (p. 257). New York, USA: Oxford University Press.

Bonsu, S. K., \& Belk, R. W. (2003). Do not go cheaply into that good night: Death-ritual consumption in Asante, Ghana. Journal of Consumer Research, 30(1), 41-55. doi:10.1086/374699

Bourdieu, P. (1984). Distinction: A social critique of the judgement of taste. Cambridge, USA: Harvard University Press.

Bourdieu, P. (1986). The forms of capital. In J. G. Richardson (Ed.), Handbook of theory and research for the sociology of education ( $\mathrm{pp}$. 241-258). London: Greenwood.
Cassia, L., Fattore, M., \& Paleari, S. (2006). Entrepreneurial strategy. Cheltenham, UK: Edward Elgar Publishing.

ChefSteps (2014). Espresso: defined. Retrieved from https://www. chefsteps.com/classes/espresso\#/espresso-defined.

Coskuner-Balli, G., \& Thompson, C. J. (2013). The status costs of subordinate cultural capital: At-home fathers' collective pursuit of cultural legitimacy through capitalizing consumption practices. Journal of Consumer Research, 40(1), 19-41. doi:10.1086/668640

Elliott, C. (2006). Considering the connoisseur: Probing the language of taste. Canadian Review of American Studies, 36(2), 229-236. doi:10.3138/CRAS-s036-02-06

Gronow, J. (1997). The sociology of taste (p. 214). London, UK: Routledge.

Hennion, A. (2001). Music lovers: Taste as performance. Culture \& Society, 18(5), 1-22. doi:10.1177/02632760122051940

Hennion, A. (2004). Pragmatics of taste. In M. Jacobs \& N. Hanrahan (Eds.), The Blackwell companion to the sociology of culture (pp. 141144). Oxford, UK: Blackwell.

Hennion, A. (2007). Thosethings thathold us together: Tasteand sociology. Cultural Sociology, 1(1), 97-114. doi:10.1177/1749975507073923

Holt, D. B. (1998). Does cultural capital structure American consumption? Journal of Consumer Research, 25(1), 1-25. doi:10.1086/209523

Karababa, E., \& Ger, G. (2011). Early modern Ottoman coffeehouse culture and the formation of the consumer subject. Journal of Consumer Research, 37(5), 737-760. doi:10.1086/656422

Kjeldgaard, D., \& Ostberg, J. (2007). Coffee grounds and the global cup: Glocal consumer culture in Scandinavia. Consumption Markets \& Culture, 10(2), 175-187. doi:10.1080/10253860701256281

Kozinets, R. V. (2001). Utopian enterprise: Articulating the meanings of Star Trek's culture of consumption. Journal of Consumer Research, 28(1), 67-88. doi:10.1086/321948

Kozinets, R. V. (2002a). Can consumers escape the market? Emancipatory illuminations from burning man. Journal of Consumer Research, 29(1), 20-38. doi:10.1086/339919

Kozinets, R. V. (2002b). The field behind the screen: Using netnography for marketing research in online communities. Journal of Marketing Research, 39(1), 61-72. doi:10.1509/jmkr.39.1.61.18935

LaTour, K. A., \& LaTour, M. S. (2010). Bridging aficionados' perceptual and conceptual knowledge to enhance how they learn from experience. Journal of Consumer Research, 37(December), 688-697. doi:10.1086/655014

LaTour, K. A., LaTour, M. S., \& Feinstein, A. H. (2011). The effects of perceptual and conceptual training on novice wine drinkers' development. Cornell Hospitality Quarterly, 52(4), 445-457. doi:10.1177/1938965511420695

Leibenstein, H. (1950). Bandwagon, snob, and Veblen effects in the theory of consumers' demand. The Quarterly Journal of Economics, 64(2), $183-207$

Levy, S. J. (1999). Meanings in advertising stimuli: Sidney J. Levy on marketing. In S. J. Levy \& D. W. Rook (Eds.), Brands, consumers, Symbols \& Research (pp. 251-255). New York, USA: Sage Publications, Inc.

Maslow, A. H. (1964). Religions, values, and peak experiences. Columbus, USA: Ohio State University Press. 
McCracken, G. (1986). Culture and consumption: A theoretical account of the structure and movement of the cultural meaning of consumer goods. Journal of Consumer Culture, 13(1), 71-84.

McQuarrie, E. F., Miller, J., \& Phillips, B. J. (2013). The megaphone effect: Taste and audience in fashion blogging. Journal of Consumer Research, 40(1), 136-158. doi:10.1086/669042

Miles, M. B., \& Huberman, A. M. (1994). Qualitative data analysis: An expanded sourcebook (Second, p. 338). London, UK: Sage Publications, Inc.

Miller, D. (1997). Material culture and mass consumption (p. 252). New York, USA: Wiley-Blackwell.

Muniz, A. M., \& O'Guinn, T. C. (2001). Brand community. Journal of Consumer Research, 27(4), 412-432. doi:10.1086/319618

Nguyen, T.-D. T., \& Belk, R. W. (2013). Harmonization processes and relational meanings in constructing Asian weddings. Journal of Consumer Research, 40(3), 518-538. doi:10.1086/671464

Otnes, C. C., \& Pleck, E. H. (2003), Cinderella dreams: The allure of the lavish wedding. Berkeley, USA: University of California Press.

Ponte, L. F., \& Mattoso, C. L. De Q. (2014). Capital cultural e o consumo de produtos culturais: As estratégias de consumo de status entre mulheres da nova classe média. Revista Brasileira de Marketing, 13(6), 18-33. doi:10.5585/remark.v13i6.2613

Ritzer, G. (2007). The McDonaldization of society (5 ed., p. 320). Thousand Oaks, USA: Pine Forge Press.

Rhinehart, R. (2017). What is specialt coffee. Retrieved from http://www. scanews.coffee/2017/03/17/what-is-specialty-coffee/

Roling, L., \& Vieira, F. G. D. (2014). Interdisciplinaridade em marketing: Perspectivas de aplicação dos conceitos teóricos de campo e habitus de Pierre Bourdieu às pesquisas em marketing. Revista de Negócios, 19(3), 58-74. doi:10.7867/1980-4431.2014v19n3p58-74

Rook, D. W. (1985). The ritual dimension of consumer behavior. Journal of Consumer Research, 12(3), 251-264.

Roseberry, W. (1996). The rise of yuppie coffees and the reimagination of class in the United States. American Anthropologist, 98(4), 762-775.

Russell, C. A., \& Levy, S. J. (2012). The temporal and focal dynamics of volitional reconsumption: A phenomenological investigation of repeated hedonic experiences. Journal of Consumer Research, 39(2), 341-359. doi:10.1086/662996

Schouten, J. W., \& McAlexander, J. H. (1995). Subcultures of consumption: An ethnography of the new bikers. Journal of Consumer Culture, 22(1), 43-61.

Sherry, Jr., J. F. (1983). Gift giving in anthropological perspective. Journal of Consumer Research, 10(2), 157-168. doi:10.1086/208956

Simon, B. (2011). Not going to Starbucks: Boycotts and the out-scouring of politics in the branded world. Journal of Consumer Culture, 11(2), 145-167.
Skeie, T. R. (2003). Norway and coffee. The Flamekeeper, (Spring), 2-5. Retrieved from https://web.archive.org/web/20031011091223/http:// roastersguild.org/052003_norway.shtm

Stebbins, R. A. (1979). Amateurs (p. 91). Beverly Hills, USA: Sage Publications.

Storey, J. (2009). Cultural theory and popular culture (Fifth, p. 266). New York, USA: Pearson.

Synnott, A. (1993). The Body Social: Symbolism, selfand society. London, UK: Routledge.

Thomas, T. C., Price, L. L., \& Schau, H. J. (2013). When differences unite: Resource dependence in heterogeneous consumption communities. Journal of Consumer Research, 39(5), 1010-1033. doi:10.1086/666616

Thompson, C. J. (1997). Interpreting consumers: A hermeneutical framework for deriving insights from the texts of consumers' consumption stories. Journal of Marketing Research, 34(4), 438-455. doi:10.2307/3151963

Thompson, C. J., \& Arsel, Z. (2004). The Starbucks brandscape and consumers' (anticorporate) experiences of glocalization. Journal of Consumer Research, 31(3), 631-642. doi:10.1086/425098

Thompson, C., Locander, W. B., \& Pollio, H. R. (1994). The spoken and the unspoken: A hermeneutic approach to understanding the cultural viewpoints that underlie consumers' expressed meanings. Journal of Consumer Research, 21(3), 432-452.

Thompson, C. J., Rindfleisch, A., \& Arsel, Z. (2006). Emotional branding and the strategic value of the doppelgänger brand image. Journal of Marketing, 70(1), 50-64.

Thornton, S. (1996). Club cultures: Music, media, and subcultural capital (p. 201). Middletown, USA: Wesleyan University Press.

Turner, B. (1984). The Body and Society. Oxford, UK: Blackwell.

Üstüner, T., \& Holt, D. B. (2010). Toward a theory of status consumption in less industrialized countries. Journal of Consumer Research, 37(1), 37-56. doi:10.1086/649759

Van Gennep, A. (1960). The rites of passage. Chicago, USA: University of Chicago Press.

Wallendorf, M., \& Arnould, E. J. (1991). "We gather together": Consumption rituals of thanksgiving day. Journal of Consumer Research, 18(1), 13-31.

Weinberger, M. F., \& Wallendorf, M. (2012). Intracommunity gifting at the intersection of contemporary moral and market economies. Journal of Consumer Research, 39(1), 74-92. doi:10.1086/662198

Wolburg, J. M., \& Treise, D. (2004). Drinking rituals among the heaviest drinkers: College student binge drinkers and alcoholics. In C. Otnes \& T. Lowrey (Eds.), Contemporary consumption rituals: A research anthology (pp. 3-20). New Jersey, USA: Lawrence Erlbaum Associates. 